\title{
Hubungan Antara Minat Belajar Dengan Hasil Belajar Fisika Peserta Didik Sma Se-Kecamatan Kota Tambolaka Tahun Ajaran 2016/2017
}

\author{
Anastasia Ndoda Ripi ${ }^{1}$, I Wayan Sukarjita², Melkianus Suluh ${ }^{2}$ \\ ${ }^{1}$ SDK Kalembu Ligha \\ ${ }^{2}$ Program Studi Pendidikan Fisika, Fakultas Pendidikan, Universtas Nusa Cendana \\ ${ }^{3}$ Program Studi Pendidikan Fisika, Sekolah Tinggi Keguran dan Ilmu Pendidikan Weetebula
}

*Anastasia Ndoda Ripi, SDK
Kalembu Ligha;
Email:
anastasiandodaripi@gmail.com
Abstrak: Penelitian ini bertujuan untuk mengetahui hubungan antara minat belajar dengan hasil belajar fisika peserta didik kelas XI IPA SMA seKecamatan Kota Tambolaka tahun ajaran 2016/2017.

Penelitian ini merupakan jenis penelitian deskriptif dengan menggunakan pendekatan korelasional. Populasi yang digunakan dalam penelitian ini adalah seluruh siswa kelas XI IPA SMA se-kecamatan Kota Tambolaka, dengan mengambil sampel 55 orang siswa. Teknik pengumpulan data melalui angket minat belajar dan tes hasil belajar siswa pada mata pelajaran fisika. Teknik analisis data untuk menguji hipotesis dilakukan dengan perhitungan statistic korelasi product moment. Hasil dari uji validitas soal tes hasil belajar siswa pada mata pelajaran fisika diperoleh 30 butir soal yang dinyatakan valid dari 35 butir soal yang diujicobakan. Hasil dari uji reliabilitas diperoleh nilai r11 sebesar 0,77 .

Berdasarkan hasil analisis data dengan menggunakan statistik parametrik yaitu uji-t diperoleh hasil $t_{\text {hitung }} 29,73>t_{\text {tabel }} 1,673$ pada taraf signifikan $5 \%$ yang berarti bahwa ada hubungan positif yang signifikan antara minat belajar dan hasil belajar peserta didik kelas XI IPA SMA se-Kecamatan Kota Tambolaka tahun ajaran 2016/2017.

Kata-kata kunci: Minat belajar, Hasil Belajar, Fisika

Abstract: This study aims to determine the relationship between interest in learning the physics learning outcomes of students of class XI IPA high schools Tambolaka City District school year 2016/2017.

This research is a correlational approach. The population used in this study were all students of class XI Science high schools in the city districts Tambolaka, by taking a sample of 55 students. Data collection through a questionnaire to test their learning and learning outcomes of students in physics. Data analysis techniques to test the hypothesis done by calculating the statistical correlation of product moment. Results of the test of the validity of test results of student learning in physics earned 30 items declared valid from 35 items tested. The results of the reliability test obtained r11 value of 0.77 .

Based on the analysis of data using statistical parametric t-test results obtained 29.731 .673 at significance level of $5 \%$, which means that there is a significant positive relationship between learning and learning outcomes of students in class XI IPA high schools in the school year Tambolaka City District 2016/2017.

Key Words: Interest in learning, learning outcomes, Physics 


\section{Pendahuluan}

UU SISDIKNAS No. 20 tahun 2003 menyatakan bahwa "pendidikan adalah usaha sadar dan terencana untuk mewujudkan suasana belajar dan proses pembelajaran agar peserta didik secara aktif mengembangkan potensi dirinya untuk memiliki kekuatan spiritual keagamaan, pengendalian diri, kepribadian, kecerdasan, akhlak mulia, serta keterampilan yang diperlukan dirinya, masyarakat, bangsa dan negara". Pernyataan tersebut dapat disimpulkan bahwa untuk mencapai tujuan pendidikan nasional yang antara lain yaitu meningkatkan ketaqwaan kepada Tuhan Yang Maha Esa, kepribadian, kecerdasan akhlak mulia, dan keterampilan, maka salah satu usaha yang ditingkatkan adalah menumbuhkan kemandirian belajar pada setiap warga negara terutama pada siswa diberbagai sekolah, dengan menumbuhkan minat dan motivasi belajar yang baik, maka prestasi belajar akan tumbuh dalam diri siswa ini, tetapi hal tersebut masih jauh dari apa yang diharapkan.

Pendidikan merupakan sarana yang tepat untuk membentuk karakter siswa sejak dini karena banyak hal yang dipelajari oleh siswa di lingkungan sekolah, mulai dari interaksi dan sosialisasi dengan teman lain, sampai seberapa jauh siswa mampu berpikir aktif dan kreatif untuk perkembangan otak. Untuk dapat melihat keberhasilan proses Kegiatan Belajar Mengajar (KBM), seluruh faktor-faktor yang berhubungan dengan guru harus dapat diperhatikan. Mulai dari perilaku guru dalam mengajar sampai dengan tingkah laku siswa sebagai timbal balik dari hasil sebuah pengajaran. Menurut Mohamad Nur (1999) "salah satu peran penting guru di dalam kelas, tidak hanya memberikan pengetahuan kepada siswa, melainkan membantu siswa untuk membangun pengetahuannya sendiri melalui pengalaman belajar. Cara yang dapat dilakukan guru adalah mengajar yang dapat menjadikan informasi yang diterima oleh siswa menjadi bermakna dan relevan bagi siswa, memberikan kesempatan kepada siswa untuk menemukan dan menerapkan sendiri ide-ide, dan mengajak siswa agar menyadari dan secara sadar dengan menggunakan strategi-strategi mereka sendiri untuk belajar" (Hatimah, 2011: 123). Kesimpulannya bahwa peran guru yang paling utama adalah sebagai fasilitator atau pengajar sedangkan siswa adalah individu yang belajar. Tingkah laku siswa ketika mengikuti proses belajar mengajar dapat mengindikasikan akan ketertarikan siswa tersebut terhadap pelajaran itu atau sebaliknya, ia merasa tertarik dengan pelajaran tersebut. Ketertarikan siswa inilah yang merupakan salah satu tanda-tanda minat.

Minat merupakan salah satu aspek psikis yang dapat mendorong manusia mencapai tujuan. Seseorang yang memiliki minat terhadap suatu objek, cenderung memberikan perhatian atau merasa senang yang lebih besar kepada objek tersebut. Namun, apabila objek tersebut tidak menimbulkan rasa senang, maka orang itu tidak akan memiliki minat terhadap objek tersebut. Oleh karena itu, tinggi rendahnya perhatian atau rasa senang seseorang terhadap objek dipengaruhi oleh tinggi rendahnya minat seseorang tersebut. Untuk membangkitkan minat itu, diantaranya dapat dilakukan dengan mengaitkan materi pembelajaran dengan situasi kehidupan yang bersifat praktis. Jika mempelajari materi pembelajaran yang dikaitkan dengan hal itu perhatian yang bersifat khusus akan muncul, karena bisa jadi materi pembelajaran yang sama, namun dikaitkan dengan kehidupan praktis akan memunculkan keterkaitan dengan segi-segi tertentu yang sangat beragam. Dari keragaman inilah setiap siswa akan menaruh perhatian khusus pada segi-segi tertentu dari kaitan-kaitan itu.

Minat pada dasarnya adalah ketika seseorang menerima akan suatu hubungan antara diri sendiri dengan sesuatu di luar diri. Adanya suatu ketertarikan yang sifatnya tetap di dalam diri subjek atau seseorang yang sedang mengalaminya atas suatu bidang tertentu dan adanya rasa senang terhadap bidang tersebut, sehingga seseorang dapat belajar dan mendalaminya. Minat mengarahkan perbuatan kepada suatu tujuan dan merupakan dorongan bagi perbuatan tersebut. Dalam usaha untuk memperoleh sesuatu, diperlukan adanya minat. Oleh karena itu, siswa berminat atau tidaknya terhadap mata pelajaran tersebut, kunci utamanya adalah ketika guru mengajar strategi apa yang akan digunakan supaya memancing perhatian dan minat belajar sehingga mendukung hasil belajar siswa.

Hasil belajar adalah hasil yang dicapai oleh siswa setelah melalui proses belajar yang di tunjukkan dalam bentuk angka, atau tindakan yang mencerminkan peserta didik dalam periode waktu tertentu dalam belajar.

Melalui kegiatan penilaian akhir guru akan mengetahui tercapai tidaknya kemampuan yang 
diharapkan dan dikuasai oleh siswa. Dengan melakukan kegiatan akhir pembelajaran, guru akan mengetahui kompetensi yang sudah dan yang belum dikuasai oleh siswa. Untuk mengetahui penguasaan siswa terhadap materi yang telah dipelajari, guru dapat memberikan test, meminta siswa untuk membuat ringkasan atau kesimpulan dari materi yang telah dibahas. Proses pembelajaran seperti inilah guru dapat mengetahui kemampuan siswa, sehingga dapat dinilai kemampuan siswa dalam bentuk angka.

Berdasarkan latar belakang inilah maka penulis tertarik untuk melakukan penelitian tentang hubungan minat belajar dan hasil belajar siswa. Oleh karena itu, Peneliti mengambil judul "Hubungan Antara Minat Belajar Dengan Hasil Belajar Fisika Peserta Didik SMA Se-Kecamatan Kota Tambolaka Tahun Ajaran 2016/2017”.

\section{Hasil dan Pembahasan}

Penelitian ini dilaksanakan bulan agustusseptember 2016. Penelitian tersebut dilaksanakan pada 3 SMA yakni: SMA Marapati dengan jumlah siswa 13 orang, SMA St. Alfonsus dengan jumlah siswa 33 orang, dan SMA Persatuan Guru Republik Indonesia (PGRI) Tambolaka dengan jumlah siswa 9 orang. Dalam penelitian ini melibatkan dua variabel yaitu minat sebagai variabel bebas yang dilambangkan dengan $\mathrm{X}$, dan hasil belajar fisika sebagai variabel terikat yang dilambangkan dengan Y. Penelitian tersebut dilaksanakan berdasarkan jadwal mata pelajaran fisika kelas XI IPA. Dalam penelitian ini, yang dilakukan peneliti yaitu: (1) pembagian angket minat belajar kepada siswa kelas XI IPA; (2) untuk mengetahui hubungan minat belajar dengan hasil belajar siswa terhadap mata pelajaran fisika, peneliti membagikan tes instrumen hasil belajar disetiap siswa dalam bentuk pilihan ganda sebanyak 35 nomor. Siswa yang menjawab benar tiap butir soal diberi skor satu (1), sedangkan siswa yang menjawab salah diberi skor nol (0).

\section{Minat Belajar}

Minat belajar adalah suatu rasa lebih suka dan ketertarikan pada suatu hal atau aktivitas tanpa ada yang menyuruh (Djamarah, 2008: 166)”. Minat pada dasarnya adalah penerimaan akan suatu hubungan antara diri sendiri dengan sesuatu di luar diri. Untuk mengetahui minat belajar peserta didik SMA se-Kecamatan Kota Tambolaka, Kabupaten Sumba Barat Daya, terhadap mata pelajaran fisika, peneliti membuat angket (koesioner) dengan jumlah indikator 6. Dari 6 indikator ini terdapat 20 soal angket minat belajar dengan pemberian skor 4 (sangat setuju), 3 (setuju), 2 (tidak setuju), 1 (sangat tidak setuju). Selanjutnya untuk melihat hasil analisis minat belajar pada SMA A. Beberapa indikator minat belajar yakni: senang, ketertarikan, perhatian, keterlibatan, suka serta perhatian, yang dapat dilihat pada tabel sebagai berikut:

Tabel 10: Presentase Minat Belajar Siswa Pada SMA Marapati.

\begin{tabular}{|c|l|c|c|}
\hline No & Indikator & $\begin{array}{l}\text { Skor } \\
\text { Minat }\end{array}$ & $\begin{array}{l}\text { Presentase } \\
(\%)\end{array}$ \\
\hline 1. & Senang & 104 & $100 \%$ \\
\hline 2. & Ketertarikan & 142 & $91 \%$ \\
\hline 3. & Perhatian & 196 & $94,23 \%$ \\
\hline 4. & Keterlibatan & 195 & $93,75 \%$ \\
\hline 5. & Suka & 91 & $89,21 \%$ \\
\hline 6. & Kesadaran & 232 & $89,23 \%$ \\
\hline
\end{tabular}

Adapun nilai minat belajar siswa dapat dilihat pada gambar di bawah ini:

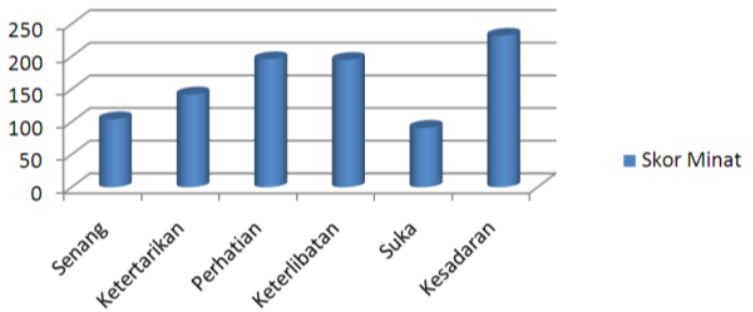

Gambar 01: Nilai Minat Belajar Siswa SMA Marapati

Berdasarkan ringkasan hasil uji angket minat pada SMA Marapati di atas dapat diketahui bahwa tingkat presentase yang sangat tinggi yaitu indikator pertama (senang) memiliki tingkat presenrase $100 \%$.

Untuk melihat hasil analisis minat belajar siswa SMA St. Alfonsus. Beberapa indikator minat belajar yakni: senang, ketertarikan, perhatian, keterlibatan, suka serta perhatian, yang dapat dilihat pada tabel sebagai berikut:

Tabel 11: Presentase Minat Belajar Siswa Pada SMA St. Alfonsus

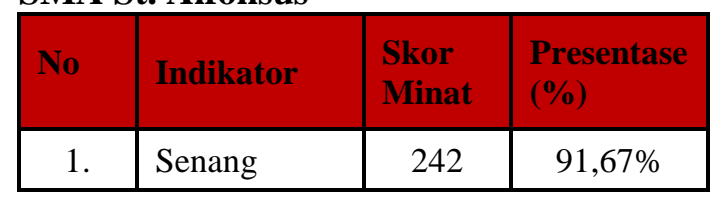




\begin{tabular}{|c|l|c|c|}
\hline 2. & Ketertarikan & 348 & $62,63 \%$ \\
\hline 3. & Perhatian & 479 & $90,72 \%$ \\
\hline 4. & Keterlibatan & 471 & $89,20 \%$ \\
\hline 5. & Suka & 243 & $91,70 \%$ \\
\hline 6. & Kesadaran & 577 & $87,42 \%$ \\
\hline
\end{tabular}

Adapun nilai minat belajar siswa dapat dilihat pada gambar di bawah ini:

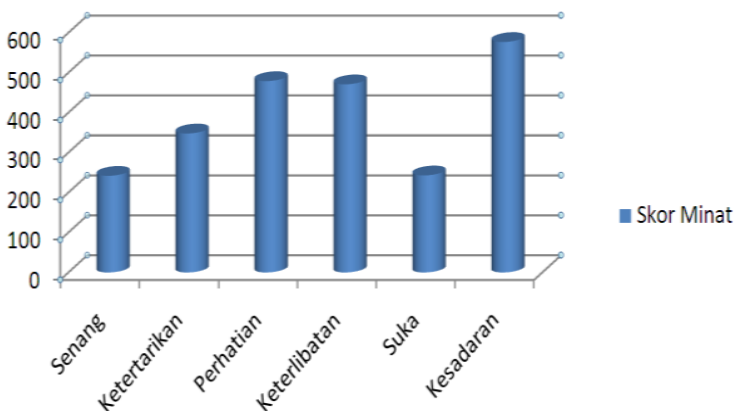

Gambar 02: Nilai Minat Belajar Siswa SMA St. Alfonsus

Berdasarkan hasil ringkasan uji angket minat pada SMA St. Alfonsus di atas dapat diketahui bahwa tingkat presentase yang sangat tinggi yaitu indikator kelima (suka) memiliki tingkat presentase $91,70 \%$.

Untuk melihat hasil analisis minat belajar siswa SMA St. Alfonsus. Beberapa indikator minat belajar yakni: senang, ketertarikan, perhatian, keterlibatan, suka serta perhatian, yang dapat dilihat pada tabel sebagai berikut:

Tabel 12: Presentase Minat Belajar Siswa Pada SMA PGRI Tambolaka.

\begin{tabular}{|c|l|c|c|}
\hline No & Indikator & $\begin{array}{l}\text { Skor } \\
\text { Minat }\end{array}$ & Presentase (\%) \\
\hline 1. & Senang & 68 & $94,44 \%$ \\
\hline 2. & Ketertarikan & 97 & $89,81 \%$ \\
\hline 3. & Perhatian & 128 & $88,89 \%$ \\
\hline 4. & Keterlibatan & 131 & $90,97 \%$ \\
\hline 5. & Suka & 66 & $91,67 \%$ \\
\hline 6. & Kesadaran & 153 & $85 \%$ \\
\hline
\end{tabular}

Adapun Gambar 03 nilai minat belajar siswa dapat dilihat di bawah ini:
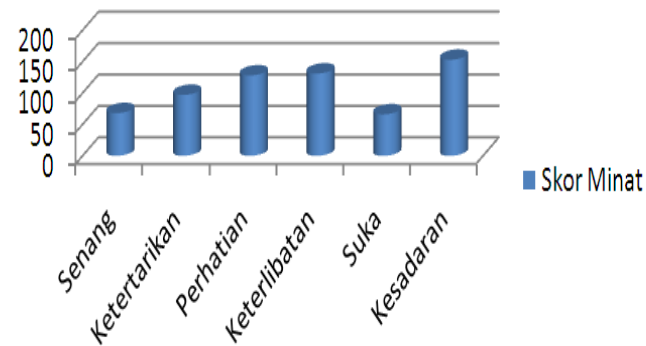

\section{Gambar 03: Nilai Minat Belajar Siswa SMA PGRI Tambolaka}

Berdasarkan hasil ringkasan uji angket minat pada SMA St. Alonsus di atas dapat diketahui bahwa tingkat presentase yang sangat tinggi yaitu indikator pertama (senang) memiliki tingkat presentase $94,44 \%$.

Untuk melihat tingkat presentase minat belajar siswa khususnya pada mata pelajaran fisika, ketiga sekolah tersebut memiliki presentase yang berbeda ditiap indikator. Agar lebih jelas dapat dilihat pada tabel umum untuk 3 SMA yang ada di Kecamatan Kota sebagai berikut:

Tabel 13: Hasil Analisis Minat Belajar Siswa Pada SMA Marapati, SMA St. Alfonsus, dan SMA PGRI Tambolaka.

\begin{tabular}{|c|c|c|c|c|c|c|c|}
\hline \multirow[t]{2}{*}{ No } & \multirow[t]{2}{*}{ Indikator } & \multicolumn{3}{|c|}{ Skor/SMA } & \multirow{2}{*}{$\begin{array}{l}\text { Jumlah } \\
\text { Total } \\
\text { Skor }\end{array}$} & \multirow{2}{*}{$\begin{array}{l}\text { Presentase } \\
\text { tiap } \\
\text { indikator }\end{array}$} & \multirow[t]{2}{*}{ Kategori } \\
\hline & & $\begin{array}{l}\text { SMA } \\
\text { Marapati }\end{array}$ & $\begin{array}{l}\text { SMASt. } \\
\text { Alfonsus }\end{array}$ & $\begin{array}{l}\text { SMLA PGRI } \\
\text { Tambolaka }\end{array}$ & & & \\
\hline 1 & Senang & 104 & 242 & 68 & 414 & $94,10 \%$ & $\begin{array}{l}\text { Sangat } \\
\text { baik }\end{array}$ \\
\hline 2 & Ketertarikan & 142 & 348 & 97 & 587 & $88,94 \%$ & $\begin{array}{l}\text { Sangat } \\
\text { baik }\end{array}$ \\
\hline 3 & Perhatian & 196 & 479 & 128 & 803 & $91,25 \%$ & $\begin{array}{l}\text { Sangat } \\
\text { baik }\end{array}$ \\
\hline 4 & Keterlibatan & 195 & 471 & 131 & 797 & $90,56 \%$ & $\begin{array}{l}\text { Sangat } \\
\text { baik }\end{array}$ \\
\hline 5 & Suka & 91 & 243 & 66 & 300 & $68,50 \%$ & Baik \\
\hline \multirow[t]{2}{*}{6} & Kesadaran & 232 & 577 & 153 & 962 & $87,45 \%$ & $\begin{array}{l}\text { Sangat } \\
\text { baik }\end{array}$ \\
\hline & Total & 960 & 2360 & 643 & 3863 & $97,48 \%$ & $\begin{array}{l}\text { Sangat } \\
\text { baik }\end{array}$ \\
\hline
\end{tabular}

Adapun Hasil Analisis Minat Belajar Siswa pada SMA Marapati, SMA St. Alfonsus, dan SMA PGRI Tambolaka dapat dilihat pada Gambar di bawah ini: 


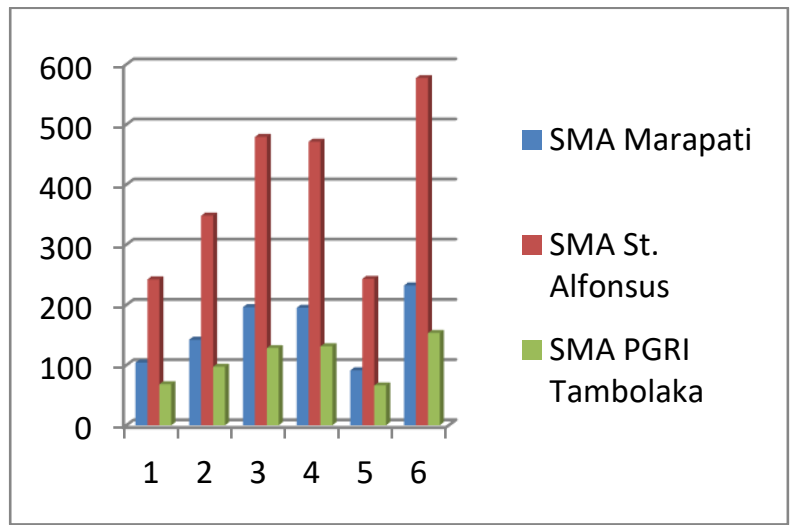

Gambar 04: Hasil Analisis Minat Belajar Siswa Pada SMA Marapati, SMA St. Alfonsus, dan SMA PGRI Tambolaka.

\section{Hasil Belajar}

Hasil belajar adalah hasil yang diperoleh siswa setelah proses pembelajaran dilaksanakan. Hasil dalam penelitian ini diperoleh dengan tes butir soal. Instrumen soal yang digunakan terdiri atas 35 butir soal pilihan ganda. Dari masingmasing butir soal memiliki 4 alternatif jawaban. Sebelum soal ini digunakan terlebih dahulu dilakukan uji validitas soal untuk mengetahui kelayakannya. Soal-soal yang digunakan dalam penelitian ini telah diuji validitasnya. Untuk mendapat validitasnya maka dilakukan uji coba instrumen soal. Uji coba ini dilakukan pada 3 sekolah yakni SMA Marapati, SMA St. Alfonsus, dan SMA PGRI Tambolaka yang bertempat di Kecamatan Kota, Kabupaten Sumba Barat Daya. Uji validitas tiap butir soal instrumen pilihan ganda menggunakan rumus validitas tes ( korelasi product moment), reliabilitas tes (KR-20), tingkat kesukaran soal, dan daya pembeda soal. Hasil yang didapat dari soal yang di uji coba diterima 30 pilihan ganda sehingga layak untuk digunakan dalam penelitian.

Berikut adalah hasil belajar yang diperoleh siswa dapat dilihat pada Tabel sebagai berikut:

Tabel 14: Nilai Hasil Belajar Siswa SMA seKecamatan Kota Tambolaka Terhadap Mata Pelajaran Fisika.

\begin{tabular}{|c|l|c|c|c|}
\hline No & Data & $\begin{array}{c}\text { SMA } \\
\text { Marapati }\end{array}$ & $\begin{array}{c}\text { SMA St. } \\
\text { Alfonsus }\end{array}$ & $\begin{array}{c}\text { SMA } \\
\text { PGRI } \\
\text { Tambolaka }\end{array}$ \\
\hline 1 & $\begin{array}{l}\text { Jumlah } \\
\text { Siswa }\end{array}$ & 13 & 33 & 9 \\
\hline 2 & $\begin{array}{l}\text { Nilai } \\
\text { Tertinggi }\end{array}$ & 100 & 88 & 100 \\
\hline 3 & Nilai & 23 & 54 & 22 \\
\hline
\end{tabular}

\begin{tabular}{|l|l|l|l|l|} 
& Terendah & & & \\
\hline & Rata-rata & $\mathbf{8 4 , 6 2}$ & $\mathbf{6 3 , 6 4}$ & $\mathbf{7 7 , 8}$ \\
\hline
\end{tabular}

Berdasarkan Tabel diatas menunjukkan bahwa hasil belajar siswa pada sekolah B lebih rendah. Untuk lebih jelasnya, nilai hasil belajar yang diperoleh setiap siswa. Telah terlihat pada tabel di atas bahwa nilai rata-rata SMA Marapati dan SMA PGRI Tambolaka dibandingkn dengan SMA St. Alfonsus.

Adapun Nilai Hasil Belajar Siswa dapat dilihat pada Gambar di bawah ini:

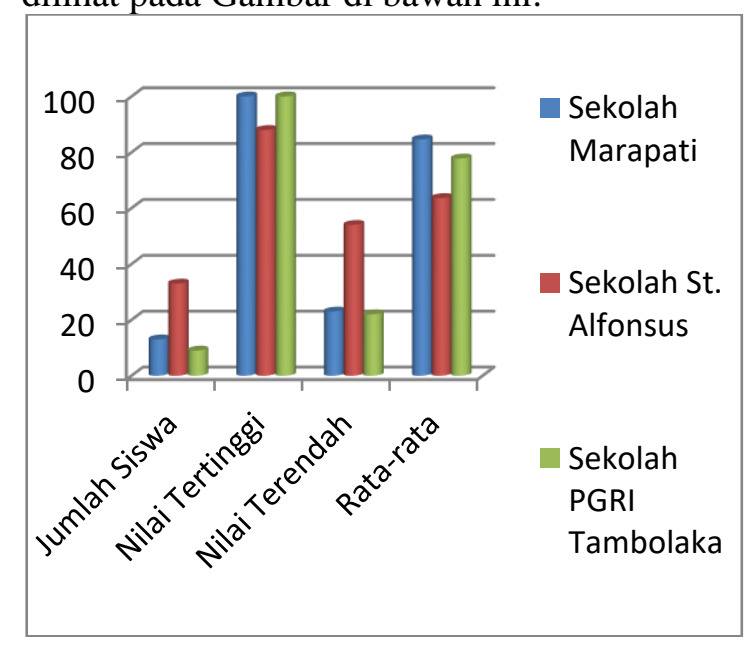

Gambar 05: Nilai Hasil Belajar Siswa SMA seKecamatan Kota Tambolaka Pada Mata Pelajaran Fisika.

Seperti pada Gambar di atas, ketiga SMA tersebut nilai rata-ratanya berada 60 ke atas. Berdasarkan data tersebut, diketahui bahwa sekolah yang nilai rata-ratanya tinggi adalah SMA Marapati dan SMA PGRI Tambolaka, dan sekolah yang nilai rata-ratanya sedang adalah SMA St. Afonsus.

\section{Hubungan Minat Belajar Dengan Hasil \\ Belajar Peserta Didik Terhadap Mata Pelajaran Fisika \\ Telah dibahas di atas bahwa dalam} penelitian ini, peneliti mengambil 3 SMA yang menjadi sampel penelitian. Ketiga SMA tersebut, minat belajar dan hasil belajar fisika peserta didik sangat berkaitan erat. Seperti yang telah ditunjukkan pada Tabel di atas (Tabel 12) bahwa minat belajar peserta didik berada pada kategori sangat baik yaitu 97,48\%. Kemudian untuk hasil belajar fisika peserta didik, telah ditunjukkan pada Tabel di atas (Tabel 13) bahwa hasil belajar peserta didik juga baik yaitu $78,49 \%$. Hal ini diketahui 
karena minat belajar baik, maka hasil belajar pun baik.

Dari data penelitian yang diperoleh menunjukkan bahwa minat belajar sangat berpengaruh terhadap hasil belajar peserta didik. Hal ini dapat diketahui dari analisis hasil kolerasi bahwa determinasi $\mathrm{r}^{2}=16,59$ yang berarti minat belajar mempengaruhi hasil belajar peserta didik. Kemudian diuji $t$ dan diperoleh $t$ hitung sebesar 29,73. Pada taraf signifikan 5\% didapatkan $t$ tabel adalah 1.673 , maka hasilnya signifikan. Ini berarti terdapat pengaruh minat belajar terhadap hasil belajar peserta didik. Hal tersebut juga dibuktikan dengan persamaan garis linear regresinya adalah $\mathrm{Y}=0,06+1,08 \bar{X}$. Sementara itu dari hasil analisis varians regresi diperoleh nilai Freg sebesar 61,63. Kemudian nilai tersebut dikonsultasikan dengan $F$ tabel, pada taraf signifikan $5 \%$ diperoleh nilai sebesar 2.389 dan taraf signifikan $1 \%$ sebesar 4.023, berarti harga Freg > Ftabel. Dari data tersebut, bahwa penelitian ini $\mathrm{H}_{l}$ diterima dan $\mathrm{H}_{0}$ ditolak, artinya minat dan hasil belajar fisika memiliki hubungan positif yang signifikan.

\section{PEMBAHASAN}

\section{Minat Belajar}

Menurut Witherington (1983: 135) minat belajar adalah kesadaran seseorang bahwa suatu objek, suatu soal atau suatu situasi mengandung sangkut-paut dengan dirinya. Sedangkan menurut Slameto (2007: 121) bahwa minat belajar adalah rasa lebih suka dan rasa ketertarikan pada suatu hal atau aktivitas, tanpa ada yang menyuruh. Namun, menurut pendapat Dalyono (1996: 56-57) berbeda dengan pendapat kedua para ahli di atas. Dalyono mengatakan bahwa minat belajar yang besar cenderung menghasilkan prestasi yang tinggi, sebaliknya minat belajar yang kurang akan menghasilkan prestasi yang rendah. Oleh karena itu, dapat disimpulkan bahwa minat belajar adalah rasa ketertarikan suatu objek yang menyangkut dirinya. Apa yang diminatinya, ia pasti memperoleh hasil yang sangat baik atau tinggi, sebaliknya apa yang tidak diminatinya ia akan memperoleh hasil yang rendah.

Berdasarkan data hasil penelitian yang dilaksanakan oleh peneliti pada 3 SMA dalam Kecamatan Kota Tambolaka, Kabupaten Sumba Barat Daya tahun pelajaran 2016/2017 diketahui bahwa minat belajar siswa untuk 3 SMA secara umum berada pada kategori sangat baik. Dari 6 indikator minat belajar, indikator yang berada di kategori sangat baik (80\%-100\%) adalah indikator $1,2,3,4$, dan 6. Pada indikator ini siswa senang dan tertarik dengan belajar fisika karena di dalam pembelajaran fisika terdapat rumus-rumus dan contoh-contoh yang berkaitan dalam kehidupan sehari-hari. Di dalam pembelajaran fisika juga terdapat banyak contoh soal yang menarik untuk mereka pecahkan dan menyelesaikannya sendiri. Hal ini terjadi dapat dilihat dari cara guru menyampaikan materi tidak membuat siswa malas ketika jam pelajaran fisika berlangsung. Fisika adalah mata pelajaran yang berkaitan dengan rumus. Ketika guru mengajar menggunakan metode ceramah dari awal pertemuan sampai akhir, tentu siswanya akan malas ketika berada di kelas dengan waktu yang cukup lama. Jika hal ini terjadi maka akan terganggu pada hasil belajar siswa yang akan dicapai. Sedangkan pada indikator 5 berada pada kategori baik (60\%-79\%). Disini ditunjukkan bahwa ketika guru menjelaskan materi, siswa memperhatikan dan aktif ketika guru bertanya. Siswa juga sering bertanya apa yang belum dimengerti dari penjelasan guru. Misalnya guru menjelaskan tentang Gerak Lurus Beraturan (GLB) dengan medianya adalah sebuah mobil mainan. Dengan membuat contoh seperti itu, siswa tidak menjadi jenuh ketika mengikuti pembelajaran fisika.

Dari data hasil penelitian yang diperoleh peneliti, bahwa ketiga (3) SMA yang berada di Kecamatan Kota Tambolaka, Sumba Barat Daya, minat belajar siswa- siswi berada pada kategori baik. Hal ini terjadi, sangat bergantung dari cara mengajar guru. Model pembelajaran, media dan metode mangajar guru adalah kunci utama guru yang harus dibawa di depan siswa ketika mengajar.

\section{Hasil Belajar}

Setiap proses belajar yang dilaksanakan oleh peserta didik akan menghasilkan hasil belajar. Hasil belajar yang baik hanya dicapai melalui proses belajar yang baik pula. Jika proses belajar tidak optimal sangat sulit diharapkan terjadinya hasil belajar yang baik.

Menurut Hamalik (2001:159) bahwa hasil belajar menunjukkan kepada prestasi belajar, sedangkan prestasi belajar itu merupakan indikator adanya derajat perubahan tingkah laku siswa. Sedangkan menurut Dimyati dan Mudjiono (2002:36) hasil belajar adalah hasil yang ditunjukkan dari suatu interaksi tindak belajar dan 
biasanya ditunjukkan dengan nilai tes yang diberikan guru.

Berdasarkan uraian di atas, maka dapat disimpulkan bahwa hasil belajar merupakan hasil yang diperoleh siswa setelah terjadinya proses pembelajaran yang ditunjukkan dengan nilai tes yang diberikan oleh guru setiap selesai memberikan materi pelajaran pada satu pokok bahasan.

Berdasarkan hasil penelitian yang diperoleh peneliti, bahwa hasil belajar yang dicapai oleh ketiga (3) SMA yang berada di Kecamatan kota Tambolaka, Kabupaten Sumba Barat Daya tidak sama. Pada SMA B nilai rata-ratanya lebih rendah dari pada SMA Marapati dan SMA PGRI Tambolaka. Hal ini dapat dilihat pada "Tabel 07 hasil belajar siswa terhadap mata pelajaran fisika kelas XI IPA". Dengan demikian pada nilai rata-rata yang rendah yaitu $=63,64$ ini (kembali melihat pada "Tabel 04 presentase minat belajar siswa)". Seperti pendapat Dalyono bahwa "minat belajar yang besar cenderung menghasilkan prestasi yang tinggi, sebaliknya minat belajar yang kurang akan menghasilkan prestasi yang rendah". Hal ini terjadi pada SMA St. Alfonsus dimana nilai ratarata $=63,64$, nilai tertinggi $=88$ dan nilai terendah $=$ 54, serta jumlah siswa 33 orang. Berbeda dengan SMA Marapati yang memperoleh nilai rata-rata= 84,62 , nilai tertinggi $=100$ dan nilai terendah $=23$, serta jumlah siswa 13 orang, sedangkan SMA PGRI Tambolaka memperoleh nilai rata-rata $=77,8$, nilai tertinggi= 100 dan nilai terendah $=22$, serta jumlah siswa 9 orang. Kedua SMA ini (SMA Marapati dan SMA PGRI Tambolaka) memperoleh hasil belajar yang tinggi karena siswanya sangat merminat pada mata pelajaran fisika.

\section{Hubungan Minat Belajar Dengan Hasil Belajar Fisika Peserta Didik SMA se- Kecamatan Kota Tambolaka}

Data yang diperoleh dari penelitian telah diolah melalui tahapan-tahapan dan ketentuanketentuan yang sudah ditentukan, dan hasil akhir yang diperoleh tersebut menentukan apakah hipotesis yang diajukan oleh penulis diterima atau ditolak. Dari data penelitian yang diperoleh menunjukkan bahwa minat belajar mempunyai hubungan erat terhadap hasil belajar peserta didik kelas XI IPA SMA se-Sekecamatan Kota Tambolaka.

Minat belajar memiliki hubungan yang signifikan terhadap mata pelajaran fisika. Hal ini dapat dibuktikan dari hasil analisis korelasi dimana determinasi $r^{2}=16,59$. Kemudian diuji $t$ dan diperoleh $t$ hitung sebesar 29,73. Pada taraf signifikan 5\% didapatkan $t$ tabel adalah 1.673, maka hasilnya signifikan. Ini berarti terdapat hubungan antara minat belajar dan hasil belajar fisika peserta didik. Hal tersebut juga dibuktikan dengan persamaan garis linear regresinya adalah $\mathrm{Y}=0,06+1,08 \bar{X}$. Sementara itu dari hasil analisis varians regresi diperoleh nilai Freg sebesar 61,63. Kemudian nilai tersebut dikonsultasikan dengan Ftabel, pada taraf signifikan 5\% diperoleh nilai sebesar 2.389 dan taraf signifikan $1 \%$ sebesar 4.023. Karena harga Freg > Ftabel , maka persamaan garis regresi tersebut menunjukkan signifikan. Ini berarti $\mathrm{H}_{0}$ ditolak sedangkan $\mathrm{H}_{l}$ diterima.

Berdasarkan data di atas, data yang diperoleh dari $t$ hitung sebesar 29,73 dimana $t$ tabelnya $=1.673$, berarti $t$ hitung $>t$ tabel. Dan juga harga $\mathrm{F}$ reg $>\mathrm{F}$ tabel yaitu 61,63, dimana pada taraf signifikan 5\% diperoleh nilai sebesar 2.389 dan taraf signifikan $1 \%$ sebesar 4.023. Hal ini dapat ditarik kesimpulan bahwa terdapat hubungan yang signifikan antara minat belajar dan hasil belajar fisika peserta didik kelas XI IPA SMA seKecamatan Kota Tambolaka tahun ajaran 2016/2017.

\section{Kesimpulan}

1. Berdasarkan hasil pembahasan pada bab sebelumnya, maka dapat disimpulkan bahwa:

Minat belajar peserta didik SMA se-Kecamatan Kota Tambolaka memperoleh tingkat persentase 97,48\%.97,48\% ini dapat dikatakan bahwa minat belajar fisika peserta didik SMA se-Kecamatan Kota Tambolaka berada pada kategori sangat baik.

2. Hasil belajar peserta didik SMA se-Kecamatan Kota Tambolaka berada angka nilai rata-rata 63 ke atas. Nilai rata-rata 63 ke atas ini merupakan angka rata-rata hasil belajar siswa baik.

3. Terdapat hubungan positif yang signifikan antara minat belajar dan hasil belajar peserta didik SMA se-Kecamatan Kota Tambolaka tahun ajaran 2016/2017. Dimana dalam penelitian ini, terdapat 3 SMA yang diteliti yakni: SMA Marapati, SMA St. Alfonsus, dan SMA PGRI Tambolaka. Hal ini dapat 
dibuktikan dari hasil analisis data dengan menggunakan uji-t ternyata $t_{\text {hitung }}>t_{\text {tabel }}$ (dengan taraf signifikan 5\%) dimana $t$ hitung $=$ 29,73 dan $t$ tabel $=1.673$, dan hipotesis diterima setelah $F$ reg diketahui yaitu $F$ reg hitung $=61,63>F$ tabel (dengan taraf $1 \%$ $=4.023$, maupun $5 \%=2.389)$.

\section{Saran}

Bersdasarkan kesimpulan hasil penelitian di atas,maka ada beberapa hal yang dapat disarankan oleh penulis sebagai berikut:

a. Bagi guru dapat melaksanakan pembelajaran yang efektif agar membangkitkan minat belajar siswa sehingga mereka tidak merasa jenuh berada dalam kelas selama pembelajaran berlangsung.

b. Siswa diharapkan lebih banyak belajar dan berlatih lebih giat dalam menyelesaikan soal yang diberikan dan dapat memperbaiaki cara belajar kearah yang lebih baik dalam hal ini untuk meningkatkan hasil belajar.

c. Kepada peneliti selanjutnya dapat menjadi acuan atau pedoman guna untuk memperoleh data-data yang akurat.

\section{Daftar Pustaka}

Anitah. 2009. Strategi Pembelajaran di SD. Jakarta: Universitas Terbuka

Anitah. 2009. Prinsip-prinsip Belajar. Jakarta: Universitas Terbuka

Aqib. 2002. Profesionalisme Guru Dalam Pembelajaran. Surabaya: Insan Cendekia

Darsono. 2000. Belajar Dan Pembelajaran. Semarang: CV Ikip Semarang

Djamarah. 2008. Psikologi Belajar. Jakarta: PT Rineka Cipta

Hilgard. 1975. Pengertian Belajar. Bandung: Refika Aditama

Hatimah. 2012. Metode pembelajaran. Bandung: CV Wacana Prima

Marno. 2014. Strategi, Metode, dan Teknik Mengajar. Yogyakarta: AR-Ruzz Media

Nasution. 2006. Kurikulum dan Pengajaran. Jakarta: PT Bumi Aksara

Purwadarmita. 2007. Pengertian Minat. Jakarta. PT Rineka Cipta
Riyanto. 2012. Paradigma Baru Pembelajaran. Jakarta: Kencana Media Group

Susanto. 2013. Psikologi Belajar. Jakarta: Prenada Media Group

Taufiq, dkk. 2010. Pendidikan Anak di SD. Jakarta: Universitas Terbuka

Witherington. 1983. Psikologi Belajar. Jakarta: Rineka Cipta 